\title{
Menakar Justice for Peace dalam Penyelesaian Sengketa Konsumen Melalui Mediasi (Studi Keputusan BPSK No. Reg. 004/REG/BPSK-DKI/L/2016) ${ }^{1}$
}

\author{
Mia Hadiati dan Mariske Myeke Tampi \\ Universitas Tarumanagara Jakarta \\ Jln. S.Parman No. 1 Jakarta Barat \\ miah@fh.untar.ac.id; marisket@fh.untar.ac.id
}

Received: 8 Desemeber 2017; Accepted: 27 Mei 2018; Published: 14 Agustus 2018

DOI: 10.20885/iustum.vol25.iss1.art5

\begin{abstract}
Consumers and business actors as seekers for justice for peace consider the decision of the Consumer Dispute Resolution Agency (BPSK) as a peace agreement letter containing the values of justice for peace. The problem analyzed in this research was the achievement of justice for peace in the decision of BPSK in Jakarta in decision No. Reg. 004/REG/BPSK-DKI//2016 dated January 22, 2016 between Andhie Saad as a consumer and Turkish Airlines as a business actor based on the principles of justice, benefit, and legal certainty. This research used qualitative method with statute approach and conceptual approach based on theories of Jeremy Bentham, John Rawls and Hans Kelsen as elements of justice for peace. The primary legal materials used were Law no. 8 of 1999 on Consumer Protection and Decree of the Minister of Industry and Trade of the Republic of Indonesia No. 350/MPP/Kep/12/2001 on the Implementation of Duties and Authority of Consumer Dispute Resolution Agency (BPSK). The analysis was carried out using philosophical-normative approach. The result of the research showed that, the resolution of Consumer Dispute through Consumer Dispute Resolution Agency (BPSK) in decision of BPSK No. Reg.004/REG/BPSK-DKI///2016 has met the values of justice for peace.
\end{abstract}

Keywords: Justice for Peace; mediation; consumer protection; the verdict of Consumer Dispute Settlement Board (BPSK)

\begin{abstract}
Abstrak
Konsumen dan pelaku usaha sebagai pencari justice for peace melihat keputusan Badan Penyelesaian Sengketa Konsumen (BPSK) sebagai akta perdamaian yang memuat nilai-nilai justice for peace. Permasalahan yang akan dianalisis di dalam penelitian ini adalah mengenai pencapaian justice for peace dalam keputusan BPSK di DKI Jakarta dalam keputusan BPSK No. Reg. 004/REG/BPSK-DKI//2016 tertanggal 22 Januari 2016 antara Andhie Saad sebagai konsumen dan Turkish Airlines sebagai pelaku usaha berdasarkan prinsip keadilan, kemanfaatan, dan kepastian hukum. Metode penelitian yang digunakan adalah metode kualitatif dengan pendekatan undang-undang dan pendekatan konseptual berdasarkan teori dari Jeremy Bentham, John Rawls dan Hans Kelsen sebagai unsur-unsur dari justice for peace. Bahan hukum primer yang digunakan yaitu UU No. 8 Tahun 1999 tentang Perlindungan Konsumen dan Keputusan Menteri Perindustrian dan Perdagangan Republik Indonesia No. 350/MPP/Kep/12/2001 tentang Pelaksanaan Tugas dan Wewenang Badan Penyelesaian Sengketa Konsumen (BPSK). Analisis dilakukan secara filosofis-normatif. Sebagai hasil penelitian, penyelesaian Sengketa Konsumen melalui Badan Penyelesaian Sengketa Konsumen (BPSK) dalam keputusan BPSK No. Reg. 004/REG/BPSK-DKI///2016 memenuhi nilai-nilai justice for peace.
\end{abstract}

Kata-kata Kunci: Justice for Peace; mediasi; perlindungan konsumen; keputusan Badan Penyelesaian Sengketa Konsumen (BPSK)

1 Merupakan penelitian lanjutan dari hibah Lembaga Penelitian dan Publikasi Ilmiah (LPPI) Fakultas Hukum Universitas Tarumanagara, Jakarta 


\section{Pendahuluan}

Mediasi sebagai salah satu alternatif penyelesaian sengketa konsumen ${ }^{2}$ pada Badan Penyelesaian Sengketa Konsumen (BPSK) secara win-win solution diharapkan memenuhi Justice for Peace (keadilan untuk perdamaian) berupa kemanfaatan, keadilan dan kepastian hukum bagi konsumen maupun pelaku usaha sebagai pencari Justice for Peace. Konflik yang tidak berkepanjangan memberi kemanfaatan berupa hematnya waktu dan biaya yang dikeluarkan oleh para pihak. Selain itu, mediasi juga seharusnya tidak mengurangi kesetaraan dari kedua belah pihak untuk mendapatkan hak yang diperjuangkannya. Kepastian hukum dari keputusan BPSK tersebut juga sangat diharapkan karena secara obyektif memberikan kemanfaatan bagi para pihak yang bersengketa berupa dapat dieksekusinya keputusan.

Proses mediasi harus dinyatakan selesai dalam waktu 21 hari $^{3}$, terlepas dari tercapai atau tidaknya perdamaian. Setelah itu, apabila tercapai perdamaian, dalam waktu 14 hari kerja terhitung sejak keputusan BPSK diberitahukan, konsumen dan pelaku usaha yang bersengketa wajib menyatakan menerima atau menolak keputusan BPSK $^{4}$. Hal ini menyiratkan kebebasan para pihak untuk memilih menerima atau menolak keputusan berupa win-win solution yang ditawarkan oleh para pihak. Dalam hal para pihak berubah pikiran dan ingin menempuh jalan win and lose solution, maka para pihak, baik konsumen maupun pelaku usaha dapat mengajukan keberatan pada Pengadilan Negeri selambatlambatnya 14 hari kerja terhitung sejak keputusan BPSK diberitahukan ${ }^{5}$. Walaupun terhadap keputusan BPSK tersebut, para pihak dapat mengajukan keberatan ke Pengadilan Negeri, keputusan BPSK merupakan keputusan yang final dan telah mempunyai kekuatan hukum yang tetap ${ }^{6}$ dengan cara penyelesaian terang dan

\footnotetext{
2 Pasal 52 huruf a UU No. 8 Tahun 1999 tentang Perlindungan Konsumen. Tugas dan wewenang BPSK meliputi "melaksanakan penanganan dan penyelesaian sengketa konsumen dengan cara melalui mediasi atau arbitrasi atau konsiliasi"

3 Pasal 38 Kepmenperindag Nomor 350/MPP/Kep/12/2001

${ }^{4}$ Pasal 41 ayat (3) Kepmenperindag Nomor 350/MPP/Kep/12/2001

${ }^{5}$ Pasal 41 ayat (4) Kepmenperindag Nomor 350/MPP/Kep/12/2001

${ }^{6}$ Pasal 42 ayat (1) Kepmenperindag Nomor 350/MPP/Kep/12/2001. Keputusan Menteri Perindustrian dan Perdagangan Republik Indonesia Nomor 350/MPP/Kep/12/2001 tentang Pelaksanaan Tugas dan Wewenang Badan Penyelesaian Sengketa Konsumen tersebut merupakan pelaksanaan Pasal 53 dan Pasal 54 Undang- Undang Nomor 8 Tahun 1999 tentang Perlindungan Konsumen, dimana di dalam kedua Pasal tersebut
} 
tunai di hadapan Majelis. Oleh karena itu, terhadap keputusan BPSK tersebut dapat dimintakan penetapan eksekusi kepada Pengadilan Negeri di tempat konsumen dirugikan?.

Akta perdamaian yang terkandung dalam keputusan BPSK tersebut merupakan bukti bahwa suatu sengketa perlindungan konsumen telah berhasil mencapai kesepakatan dan telah berhasil diselesaikan dengan pranata mediasi, sehingga efektif atau tidaknya mediasi dalam penyelesaian sengketa konsumen pada BPSK tersebut akan terlihat melalui perbandingan antara banyaknya akta perdamaian yang terbentuk dengan banyaknya perkara yang ditempuh melalui mediasi pada BPSK tersebut. Semakin banyak akta perdamaian yang terbentuk berarti semakin banyak sengketa yang telah berhasil diselesaikan. Oleh karena itu, semakin banyak sengketa yang berhasil diselesaikan berarti semakin efektif pula penyelesaian sengketa yang dilakukan melalui mediasi pada BPSK di DKI Jakarta tersebut.

\section{Gambar 1.}

Perbandingan antara pemilihan pranata arbitrase, mediasi dan konsiliasi di BPSK DKI Jakarta

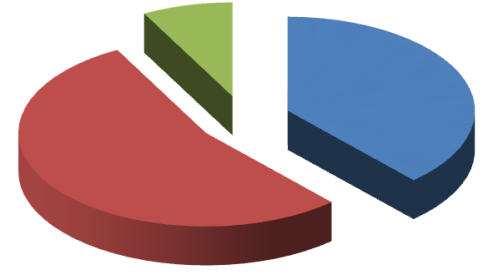

Arbitrase $(37,78 \%)$

mediasi (53,2\%)

- Konsiliasi $(7,74 \%)$

Sumber: Penelitian Mia Hadiati dan Mariske Myeke Tampi, Jurnal Hukum Prioris - Universitas Trisaksi

Berdasarkan hasil penelitian terdahulu yang dilakukan oleh Mia Hadiati dan Mariske Myeke Tampi mengenai "Efektivitas Mediasi dalam Penyelesaian Sengketa Konsumen oleh Badan Penyelesaian Sengketa Konsumen (BPSK) di D.K.I. Jakarta"8 diketahui bahwa mediasi cenderung dipilih pada BPSK di DKI Jakarta, khususnya pada Sub Direktorat Pemberdayaan dan Perlindungan Konsumen Kementerian Perdagangan Republik Indonesia (Subdit PPK Kemendag

\footnotetext{
diamanatkan mengenai pelaksanaan tugas dan wewenang penyelesaian sengketa konsumen dalam bentuk majelis oleh BPSK, dimana keputusan majelis tersebut bersifat final dan mengikat.

${ }^{7}$ Pasal 42 ayat (2) Kepmenperindag Nomor 350/MPP/Kep/12/2001

${ }^{8}$ Mia Hadiati dan Mariske Myeke Tampi, "Efektivitas Mediasi dalam Penyelesaian Sengketa Konsumen oleh Badan Penyelesaian Sengketa Konsumen (BPSK) di D.K.I. Jakarta”, Jurnal Hukum Prioris, Vol. 6 No. 1 Tahun 2017, 64-80, hlm. 75. Penelitian ini dilakukan di 2 (dua) tempat yaitu di Badan Penyelesaian Sengketa Konsumen DKI Jakarta dan Sub Direktorat Pemberdayaan dan Perlindungan Konsumen Kementerian Perdagangan Republik Indonesia (Subdit PPK Kemendag RI)
} 
RI). Pranata mediasi dipilih sebagai jalur penyelesaian sengketa pada Subdit PPK sebanyak 53,2\% (2496 perkara). Persentase tersebut merupakan persentase terbesar dibanding pranata arbitrase sebanyak 37,78\% (1773 perkara) dan konsiliasi sebanyak 7,74\% (363 perkara). Total keseluruhan perkara yang selesai diproses oleh Subdit PPK Kemendag RI melalui ketiga pranata tersebut dalam kurun waktu 13 (tiga belas) tahun tersebut adalah sebanyak 4692 perkara9 9

Hal ini membuktikan bahwa mediasi pada BPSK DKI Jakarta khususnya pada Subdit PPK Kemendag RI dinilai efektif untuk menyelesaikan perkara oleh para pihak. Namun demikian, perlu ditelaah lebih lanjut, setelah perkara berhasil diputus dalam mediasi apakah keputusan tersebut membawa Justice for Peace bagi kedua belah pihak atau tidak. Oleh karena itu, para peneliti tertarik untuk melakukan penelitian lebih lanjut terhadap 1 keputusan Badan Penyelesaian Sengketa Konsumen di DKI Jakarta. Keputusan yang hendak diteliti adalah keputusan BPSK No. Reg. 004/REG/BPSK-DKI/I/2016, antara Andhie Saad sebagai konsumen dan Turkish Airlines sebagai pelaku usaha.

\section{Rumusan Masalah}

Bagaimana pencapaian Justice for Peace (keadilan untuk perdamaian) dalam keputusan BPSK di DKI Jakarta khususnya dalam Keputusan BPSK No. Reg. 004/REG/BPSK-DKI/I/2016 berdasarkan prinsip keadilan, kemanfaatan dan kepastian hukum?

\section{Tujuan Penelitian}

Untuk mengetahui lebih dalam mengenai pencapaian Justice for Peace (keadilan untuk perdamaian) dalam keputusan BPSK di DKI Jakarta khususnya dalam Keputusan BPSK No. Reg. 004/REG/BPSK-DKI/I/2016 berdasarkan prinsip keadilan, kemanfaatan dan kepastian hukum.

9 Wawancara dengan Bpk. Jerry Ephraim Caraen, Kepala Seksi Konsultasi Hukum Sub Direktorat Pemberdayaan dan Perlindungan Konsumen (Subdit PPK), 19 Oktober 2016, Kementerian Perdagangan Republik Indonesia 


\section{Metode Penelitian}

Penelitian ini merupakan penelitian yang bersifat normatif dengan analisis kualitatif. Metode pendekatan yang digunakan dalam penelitian ini pendekatan konseptual $^{10}$ terhadap mediasi pada BPSK di DKI Jakarta dan keputusan BPSK itu sendiri. Analisis secara filosofis-normatif dilakukan terhadap Keputusan BPSK DKI Jakarta No. Reg. 004/REG/BPSK-DKI/I/2016, berdasarkan konsep dari teori Jeremy Bentham, John Rawls dan Hans Kelsen sebagai unsur-unsur dari Justice for Peace. Bahan hukum primer yang digunakan yaitu Undang-Undang No. 8 Tahun 1999 tentang Perlindungan Konsumen dan Keputusan Menteri Perindustrian dan Perdagangan Republik Indonesia No. 350/MPP/Kep/12/2001 tentang Pelaksanaan Tugas dan Wewenang Badan Penyelesaian Konsumen (BPSK). Bahan Non-Hukum diperoleh melalui wawancara dengan Dr. Djainal A. Simanjuntak, Hakim Mediator BPSK DKI Jakarta dan Bpk. Jerry Ephraim Caraen, Kepala Seksi Konsultasi Hukum Sub Direktorat Pemberdayaan dan Perlindungan Konsumen, Kementerian Perdagangan Republik Indonesia.

\section{Hasil Penelitian dan Pembahasan}

\section{Definisi Justice for Peace dalam Sengketa Konsumen Melalui Mediasi}

Sebelum menelaah definisi perdamaian secara harfiah, perlu melihat latar belakang dibutuhkannya perdamaian. Jika perdamaian dibutuhkan, maka berarti sebelumnya telah terjadi perang. "Perang" dalam bahasa ilmu hukum disebut oleh Satjipto Rahardjo sebagai spannungverhaltnis, ${ }^{11}$ yaitu adanya tarik-menarik antara ketiga nilai dasar hukum, yaitu unsur kepastian hukum, keadilan dan kemanfaatan. Tarik-menarik mana memunculkan sebuah konklusi terbaik sebagai akibat bekerjanya oleh para pemangku kepentingan (stakeholders) yaitu konsumen,

\footnotetext{
10 Peter Mahmud Marzuki, Penelitian Hukum, Kencana, Jakarta, 2006, hlm. 137

${ }^{11}$ Satjipto Raharjo, Hukum dan Perubahan Sosial, PT. Citra Aditya Bakti, Bandung, 1980, hlm. 78. Lihat juga Satjipto Raharjo, Ilmu Hukum, PT. Citra Aditya Bakti, Bandung, 2006. Menurut Radbruch nilai-nilai dasar dari hukum meliputi keadilan, kemanfaatan dan kepastian hukum. Walaupun ketiganya merupakan nilai dasar dari hukum, namun spannungsverhaltnis tidak bisa terhindarkan karena masing-masing unsur berlainan arah sehingga sangat berpotensi terjadi "perang". Bandingkan dengan Soejono Soekanto, Faktor-Faktor yang Mempengarubi Penegakan Hukum, Raja Grafindo Persada, Jakarta, 1983, hlm. 8. Inti dan arti penegakan hukum terletak pada kegiatan menyerasikan hubungan unsur-unsur nilai yang pada akhirnya bertujuan untuk menciptakan, memelihara, dan mempertahankan kedamaian pergaulan hidup dalam masyarakat.
} 
pelaku usaha dan penengahnya yaitu Badan Penyelesaian Sengketa Konsumen (BPSK).

"Justice" diartikan sebagai "fairness in the way people are dealt with"12, sedangkan "peace" diartikan sebagai "freedom from war and violence, especially when people live and work together happily without disagreements"13. Justice for Peace merupakan keadilan untuk mencapai kesepakatan atas sengketa sehingga masing-masing pihak mendapatkan kedamaian ${ }^{14}$.

\section{Mekanisme Pencapaian Justice for Peace dalam Mekanisme Penyelesaian Sengketa Melalui Mediasi pada Badan Penyelesaian Sengketa Konsumen (BPSK)}

Mediasi pada Badan Penyelesaian Sengketa Konsumen (BPSK) memiliki definisi: 15

"Mediasi adalah proses penyelesaian sengketa konsumen di luar pengadilan dengan perantaraan BPSK sebagai penasehat dan penyelesaiannya diserahkan kepada para pihak."

Mediasi diharapkan menjadi wadah bagi para pihak untuk mencapai Justice for Peace. Oleh karena perdamaian tersebut dicapai oleh karena sebelumnya telah terjadi sengketa terhadap kesepakatan, maka perlu dipertimbangkan secara wajar mengenai tiga nilai dasar yang membentuk kesepakatan sebagai hukum bagi para pihak yang mengadakannya. Berikut ini gambar mengenai Mekanisme Penyelesaian Sengketa Melalui Mediasi pada BPSK:16

${ }^{12}$ Cambridge Advanced Learner's Dictionary, $4^{\text {th }}$ Edition, edited by Colin Mc. Intosh, Cambridge University Press, United Kingdom, 2013, hlm. 846

${ }^{13}$ John Rawls, A Theory of Justice, Harvard University Press, Cambridge, 1991, hlm. 129.

Dapat diunduh pada: https://www.google.co.id/url?sa $=t \& r c t=j \& q=\& e s r c=s \&$ source $=$ web\&cd $=$ $1 \& \mathrm{cad}=$ rja\&uact $=8 \&$ ved $=0$ ahUKEwiZ2sPl_aDTAhVDL48KHSghBK4QFggjMAA\&url=http $\% 3 \mathrm{~A} \% 2 \mathrm{~F} \% 2 \mathrm{Fw}$ ww.univpgri-palembang.ac.id $\% 2$ Fperpus-fkip $\% 2$ FPerpustakaan $\% 2$ FAmerican $\% 2520$ Phylosophy $\% 2$ FJohn $\% 2520$ Rawls $\% 2520-\% 2520 \mathrm{~A} \% 2520$ Theory $\% 2520$ of $\% 2520$ Justice $\% 2520$ Revised $\% 2520$ Edition.pdf\&usg= AFQjCNEVQ_9Aet_EWSt_FohNg6ToXDWSWg

${ }^{14}$ Bandingkan dengan Kimberley Armstrong, "Justice without Peace? International Justice and Conflict Resolution in Northern Uganda", Development \& Change, May2014, Vol. 45 Issue 3, p589-607. 19p, DOI: 10.1111/dech.12090. Walaupun beranjak dari kacamata yang berbeda, ternyata keadilan bisa mendatangkan perdamaian, bisa juga tidak mendatangkan perdamaian.

15 Pasal 1 angka 10 Kepmenperindag Nomor 350/MPP/Kep/12/2001

${ }^{16}$ Mekanisme Penyelesaian Sengketa Melalui BPSK dan hubungannya dengan penyelesaian sengketa di Pengadilan dapat dilihat dalam Mia Hadiati dan Mariske Myeke Tampi, Op. Cit., hal. 74 
Gambar 2.

Mekanisme Penyelesaian Sengketa Melalui Mediasi pada BPSK yang harus ditempuh dalam 21 hari (Pasal 38 Kepmenperindag Nomor 350/MPP/Kep/12/2001)

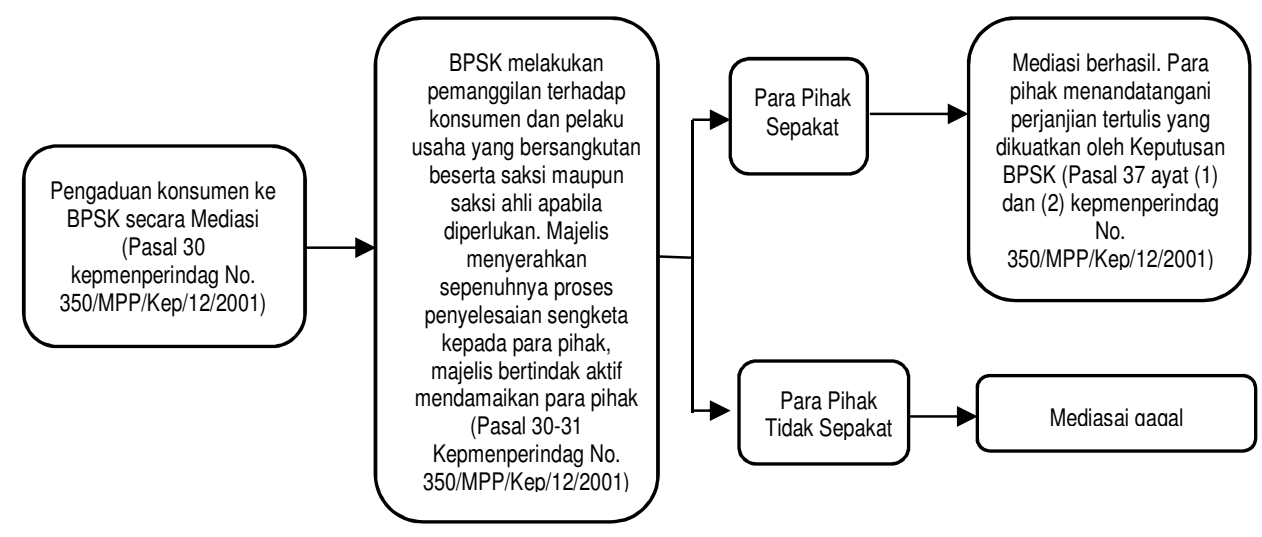

Justice for Peace (Keadilan untuk Perdamaian) Berupa Nilai Kemanfaatan Bagi Sejumlah Besar Orang (The Greatest Happiness for The Greatest Number) dalam Mediasi

Konsumen dan pelaku usaha yang memilih menggunakan jalur mediasi dalam mencapai kesepakatan pada umumnya memilih berdasarkan praktisnya penyelesaian melalui mediasi. Sebagaimana kebahagiaan yang diberikan oleh adanya nilai kemanfaatan, kebahagiaan tersebut juga merupakan sasaran terutama yang hendak dicapai oleh para pihak ketika memilih mediasi sebagai jalur pencapaian kesepakatan. Mediasi dianggap memiliki "pintu keluar" yang paling cepat dan paling terjangkau. Bekerjanya hukum dianggap paling efektif ketika pintu keluarnya cepat dan biayanya terjangkau.

Para penegak hukum pun merancang mediasi agar dapat memberikan kemanfaatan atau kebahagiaan yang sebesar-besarnya bagi sebanyak-banyaknya masyarakat dengan memberikan pintu keluar yang cepat dan terjangkau. Nilai kemanfaatan ini didasarkan pada pemikiran Jeremy Bentham: "Nature has placed mankind under the governance of two souvereign masters, pain and pleasure."17

Jeremy Bentham menganggap penerapan dari nilai kemanfaatan sebagai antithesis dari rasa sakit atau penderitaan. Oleh karena itu, menurutnya,

${ }^{17}$ Jeremy Bentham, An Introduction to the Principles of Moral and Legislation, Kitchener, Ontario, 2000, Dapat diunduh pada: www.earlymoderntexts.com/assets/pdfs/bentham1780.pdf, hlm. 14 
penerapan hukum juga tidak boleh membawa rasa sakit atau penderitaan kepada masyarakat pada umumnya, sebagaimana yang dikatakannya dalam pernyataan:

"The interest of the community is one of the most general expression that can occur in the phraseology of morals: no wonder that the meaning of it is often lost. When it has a meaning, it is this. The community is a fictitious body, composed of the individual persons who are considered as constituting as it were its members. The interest of the community then is, what is it? ---the sum of interest of the several members who compose it. ${ }^{18}$

Di dalam pernyataannya tersebut, ia juga menyatakan bahwa kepentingan kelompok adalah jumlah dari kepentingan-kepentingan dari beberapa anggota di dalamnya. Hal tersebut menyatakan bahwa Jeremy Bentham melihat kelompok, bukan secara keseluruhan, melainkan sebagai kumpulan individu yang memiliki kepentingannya masing-masing (for the interest of an individual). Kepentingan yang sama dari masing-masing individu tersebut dikumpulkan sebagai kepentingan umum yang kemudian diprioritaskan untuk dicapai sebagai bentuk dari pemberian kebahagiaan kepada kelompok tersebut (the sum of interest of the several members who compose it). Hal ini ditegaskannya dalam pernyataan:

"It is in vain to talk of the interest of the community, without understanding what is the interest of the individual. A thing is said to promote the interest, or to be for the interest of an individual, when it tends to add the sum total of his pains."19

Berdasarkan pernyataan tersebut, dapat dikemukakan bahwa jika ditinjau dari dasar pemikiran pemberlakuan mediasi oleh pemerintah yaitu:

"bahwa mediasi merupakan cara penyelesaian sengketa secara damai yang tepat, efektif dan dapat membuka akses yang lebih luas kepada para pihak untuk memperoleh penyelesaian yang memuaskan serta berkeadilan.... Mediasi sebagai instrumen untuk meningkatkan akses masyarakat terhadap keadilan sekaligus implementasi asas penyelenggaraan peradilan yang sederhana, cepat dan berbiaya ringan." 20

Mediasi sejatinya merupakan jalur penyelesaian perkara yang memberi kebahagiaan kepada masyarakat secara umum (sebagai kumpulan dari individu)

\footnotetext{
${ }^{18}$ Jeremy Bentham, Op. Cit., hlm. 15

19 Jeremy Bentham, Ibid.

${ }^{20}$ Konsiderans Peraturan Mahkamah Agung RI Nomor 1 Tahun 2016. Lihat juga Pasal 52 Undang-Undang No. 8 Tahun 1999 jo. Pasal 3 Kepmenperindag Nomor 350/MPP/Kep/12/2001. Dalam kedua peraturan tersebut diatur mengenai mediasi sebagai salah satu cara penanganan dan penyelesaian sengketa konsumen selain arbitrase dan konsiliasi.
} 
dengan mengimplementasikan asas penyelenggaraan peradilan yang sederhana, cepat dan berbiaya ringan (sebagai akumulasi dari kepentingan masing-masing individu masyarakat). Berdasarkan hal tersebut, penyelenggaraan mediasi berarti mendukung adanya efektivitas dari segi hukum secara prosedural bagi masyarakat pencari keadilan, sehingga kemanfaatan terhadap para pihak dinilai dari segi memberikan manfaat secara prosedural yaitu pengimplementasian penyelenggaraan peradilan yang sederhana, cepat dan berbiaya ringan (selanjutnya disebut sebagai efektivitas dari segi hukum secara prosedural).

\section{Justice for Peace (Keadilan untuk Perdamaian) berupa Kesetaraan (Fairness) Para Pihak dalam Mediasi}

Menurut John Rawls:

"Since all are similarly situated and no one is able to design principles to favor his particular condition, the principles of justice are the result of a fair agreement or bargain." 21

John Rawl melihat individu sebagai bagian dari kelompok, dengan cara melihat dahulu kepentingan kelompok baru kemudian melihat pada kepentingan individu ${ }^{22}$. Bahwa setiap orang diposisikan sama (similarly situated) seperti orang lain di dalam kelompok tersebut. Jika dilihat dari sudut pandang mediasi, ada suatu titik temu antara pendekatan Rawls dan Bentham mengenai bagaimana melihat individu sebagai subjek hukum yang memiliki kepentingan sebagai pribadi dan ia pula sebagai bagian dari kelompok. Kepentingan pribadi dan kepentingan kelompok akan saling berpotongan menghasilkan kewajaran ${ }^{23}$ di antara keduanya.

${ }^{21}$ John Rawls, Ibid., hlm. 11.

${ }^{22} \mathrm{Hal}$ yang sama juga dikemukakan dalam analisis pemikiran John Rawl yang ditulis oleh Josse Klijsnma bahwa "the role of justice, and more specifically of principles of social justice, is to offer a system to fairly divide the gains and burdens of social cooperation. By this Rawls means that his theory focuses not on individual actions, but on the basic structure of society. It is this social cooperation that creates mutual advantage." Dalam tulisan tersebut ia mengungkapkan bahwa kesetaraan yang dimaksud oleh John Rawl adalah keadilan sosial dan tidak berfokus semata-mata pada perbuatan individu, tetap pada struktur dasar dari msyarakat. Lihat Josse Klijsnma, "Contract Law as Fairness", Ratio Juris, Mar 2015, Vol. 28 Issue 1, p.68-88. 21p., hlm. 69-70.

${ }^{23}$ Lihat juga pendapat tentang pemikiran John Rawl yang dikemukakan oleh Michael Anthony Lawrence, seorang profesor dari Michigan State University College of Law dan pengarang buku Radicals in Their Own Time: Four Hundred Years of Struggle for Liberty and Equal Justice in America (2011) mengenai konsep "reciprocity", kewajaran mengandung prinsip resiprositas. Lihat Michael Anthony Lawrence, "Justice-as-Fairness as Judicial Guiding Principle”, Brooklyn Law Review, Winter2016, Vol. 81 Issue 2, p673-731. 59p. hlm. 678. Selanjutnya bandingkan dengan Chiara Cordelli, "Justice as Fairness and Relational Resources", Journal of Political Philosophy, Mar 2015, Vol. 23 Issue 1, p86-110. 25p. DOI: 10.1111/jopp.12036. 
Jika kedua belah pihak yaitu konsumen dan pelaku usaha dilihat sebagai kelompok, maka mereka memiliki kesamaan kepentingan secara prosedural yaitu peradilan yang sederhana, cepat dan berbiaya ringan. Tetapi jika dilihat dari sudut pandang individu maka masing-masing mereka datang ke dalam proses mediasi yang sederhana, cepat dan berbiaya ringan tersebut dengan masing-masing kepentingan berupa hak yang hendak diperjuangkan, hak mana tidak bisa secara serta-merta ditiadakan atau dikurangi tanpa dasar hukum yang jelas. Apalagi jika telah ada kesepakatan (mutual consent) di antara para pihak dimana disana telah tertera hak dan kewajiban masing-masing pihak secara jelas. Sengketa berupa wanprestasi yang terjadi tetaplah harus diproses secara adil, tanpa mengurangi hak dari kedua belah pihak. Keputusan BPSK justru mendorong para pihak untuk saling memenuhi kewajibannya seperti yang tertera dalam mutual consent tersebut.

Penyelesaian sengketa dengan cara win-win solution mencerminkan adanya keseimbangan antara konsumen dan pelaku usaha yang bersengketa dari sisi "tawarmenawar" setelah adanya mutual consent atau menurut John Rawls, perjanjian atau tawar-menawar yang setara (a fair agreement or bargain). Tawar-menawar setelah mutual consent sendiri dapat dianggap sebagai wanprestasi bagi salah satu pihak yang telah berharap adanya pemenuhan prestasi dari pihak lainnya sesuai dengan mutual consent. Pendekatan win-win solution tidak sepenuhnya merupakan penyelesaian sengketa yang memenuhi kepastian hukum secara material, melainkan merupakan pengejawantahan rasa keadilan di antara kedua belah pihak. Rasa keadilan mana merupakan titik temu dari dua kepentingan. Titik temu yang merupakan hasil pertemuan dari kesepakatan yang memberi kemanfaatan wajar bagi kedua belah pihak: "Since all are similarly free and rational, each must have an equal say in adopting the public principles of the ethical commonwealth." 24

Setiap pihak dianggap bebas dan rasional (free and rational) dalam menentukan mutual consent di antara mereka, sehingga adalah hal yang fair, jika masing-masing pihak juga melakukan tanggung jawabnya sesuai dengan keputusan bebas dan rasional tersebut (selanjutnya disebut sebagai Efektivitas dari Segi Hukum secara Material). Dengan bantuan BPSK diharapkan mendorong

${ }^{24}$ Ibid., hlm. 226 
pemenuhan tanggung jawab dari kedua belah pihak sehingga dengan pemenuhan tanggung jawab tersebut, masing-masing memperoleh haknya. Inilah hakikat dari prinsip win-win solution dalam mediasi, saling membuat pihak lain menang.

\section{Justice for Peace (Keadilan untuk Perdamaian) berupa Validitas Hukum (Legal Validity) dalam Mediasi}

Efektivitas hukum diawali dengan validitas hukum. Dalam bukunya Reine Rechtslehre (Pure Theory of Law) Hans Kelsen menjelaskan sebagai berikut ${ }^{25}$ :

"A legal norm becomes valid before becomes effective, that is before it is applied and obeyed; a law court that applies a statute immediately after promulgation - therefore before the statute had a chance to become "effective" - applies a valid legal norm. But a legal norm is no longer considered to be valid, if it remains permanently ineffective. Effectiveness is a condition of validity in the sense that effectiveness has to join the positing of a legal norm is not to lose its validity."

Menurut Hans Kelsen, suatu aturan hukum harus dalam keadaan valid ${ }^{26}$ terlebih dahulu baru diketahui apakah aturan tersebut dapat menjadi efektif ${ }^{27}$. Jika setelah diterapkan ternyata peraturan yang sebenarnya sudah valid tersebut ternyata tidak dapat diterapkan atau tidak dapat diterima oleh masyarakat secara meluas dan/atau secara terus-menerus, maka ketentuan hukum tersebut menjadi hilang unsur validitasnya, sehingga berubah sifat dari aturan yang valid menjadi aturan yang tidak valid 28 .

${ }^{25}$ Hans Kelsen dalam Munir Fuady, Teori-teori Besar (Grand Theory) dalam Hukum, Prenada Media Group, Jakarta, 2013, hlm. 117

${ }^{26}$ Validitas tersebut ditunjang dengan adanya konsep "rule of recognition" dari H.L.A. Hart dalam mediasi di DKI Jakarta seperti dalam Philippe Gérard, "On Some Presuppositions of Judgments of Legal Validity", Ratio Juris, Jun2016, Vol. 29 Issue 2, p280-287. 8p. DOI: 10.1111/raju.12128, hlm 281, bahwa, "Among the secondary rules adopted in modern legal systems, the rules of recognition play a decisive role in the justification of the validity of legal norms. These rules lay down the criteria in the light of which a norm can be considered as a valid legal norm that should be applied by legal officials. The idea of the "rule of recognition" has been put forward by Herbert Hart to explain this form of reflexivity that is characteristic of the legal systems."

${ }^{27}$ Efektif tidaknya sebuah aturan ditunjang pula dengan kemampuan hukum itu sendiri untuk memiliki otoritas yang sah (capability of possessing legitimate authority), seperti yang diungkapkan dalam Matthew H. Kramer, "Moral Principles and Legal Validity", Ratio Juris, Mar2009, Vol. 22 Issue 1, p44-61. 18p. DOI: 10.1111/j.14679337.2008.00411.x., hlm. 46. Kemampuan untuk memiliki otoritas yang sah berproses dari penyerapan norma ke dalam hukum, lalu hukum tersebut dipisahkan bentuknya dari norma sehingga menjadi hukum positif yang memiliki otoritas keberlakuan dalam suatu ruang dan waktu. Lihat Giorgio Pino, "Positivism, Legal Validity, and Separation of Law and Morals”, Ratio Juris, Jun2014, Vol. 27 Issue 2, p190-217. 28p. DOI: 10.1111/raju.12044., hlm. 192

${ }^{28}$ Bandingkan dengan bagaimana hukum dapat diterima dan menjadi valid dalam masyarakat yang sangat menjunjung hak asasi manusia dalam hal menerima atau menolak suatu ketentuan hukum. Lihat Ota Weinberger, "Legal Validity, Acceptance of Law, Legitimacy: Some Critical Comments and Constructive Proposals", Ratio Juris. Dec1999, Vol. 12 Issue 4, p336. 18p. 
Dalam bukunya, Introduction to The Problem of Legal Theory, dikatakan bahwa ${ }^{29}$ : "It (positive law) characterizes itself as a 'pure' theory of law because it aims at cognition focused on the law alone...". Agar perdamaian yang dilakukan oleh para pihak memiliki validitas, maka mediasi harus memiliki dasar hukum yang valid dan keputusan mediasi harus dapat dieksekusi. Mediasi memiliki dasar hukum yang valid yaitu Undang-Undang No. 8 Tahun 1999 tentang Perlindungan Konsumen, Keputusan Menteri Perindustrian dan Perdagangan Republik Indonesia Nomor: 350/MPP/Kep/12/2001dan Peraturan Mahkamah Agung RI Nomor 1 Tahun 2016 tentang Prosedur Mediasi di Pengadilan. Mediasi pada BPSK juga menghasilkan keputusan yang final dan mengikat sebagaimana tercantum dalam Pasal 37 ayat (1) dan (2) Kepmenperindag No. $350^{30}$

"Penyelesaian sengketa konsumen ... dengan cara Mediasi dibuat dalam perjanjian tertulis yang ditandatangani oleh para pihak yang bersengketa. Perjanjian tertulis tersebut dikuatkan dalam bentuk keputusan BPSK."

Agar dapat adil dan bermanfaat, keputusan mediasi harus dapat dieksekusi (selanjutnya disebut sebagai Efektivitas dari Segi Hukum secara Eksekutorial). Dalam prakteknya, eksekusi dilakukan di depan Majelis dengan menyerahkan bukti setor sebagai bentuk pemenuhan kewajiban dalam perjanjian tertulis antara para pihak yang dikuatkan oleh Keputusan BPSK. Penyerahan bukti setor tersebut meniru cara dalam hukum Adat yaitu terang dan tunai. Terang merujuk pada penyelesaiannya dilakukan di hadapan Majelis dan tunai merujuk pada penyerahan bukti setor, yang merupakan cara pelunasan masa kini.

\footnotetext{
${ }^{29}$ Hans Kelsen, Introduction to The Problem of Legal Theory, Oxford University Press, New York, 2002, hlm. 7. Dapat diunduh pada: https: $/ /$ www.google.co.id $/$ url? $s a=t \& r c t=j \& q=\& e s r c=s \&$ source $=$ web $\& c d=2 \& c a d=$ rjakuact $=8 \&$ ved $=0$ ahUKEwiU3Jnh2qDTAhXMQI8KHa75CqYQFggqMAE\&url=http $\% 3 \mathrm{~A} \% 2 \mathrm{~F} \% 2$ Fisites.har vard.edu $\% 2 \mathrm{Ffs} \% 2 \mathrm{Fdocs} \% 2$ Ficb.topic1134127.files $\% 2$ FFebruary $\% 252014 \% 2520$ Readings $\% 2$ FKelsen $\% 2520$ \%2520Intro\%2520to\%2520the\%2520Problems\%2520of\%2520Legal\%2520Theory.pdf\&usg=AFQjCNEZSam PqTUUyGYevFBGI2SYhR8e'Tg

${ }^{30}$ Pasal 37 ayat (1) dan (2) Keputusan Menteri Perindustrian dan Perdagangan Republik Indonesia Nomor 350/MPP/Kep/12/2001 tentang Pelaksanaan Tugas dan Wewenang Badan Penyelesaian Sengketa Konsumen. Harap diingat bahwa Keputusan BPSK berbeda dengan Putusan BPSK. Keputusan BPSK dihasilkan melalui Mediasi dan Konsiliasi sedangkan Putusan BPSK dihasilkan melalui Arbitrase.
} 
Menakar Justice for Peace (Keadilan untuk Perdamaian) Berupa Nilai Kemanfaatan Bagi Sejumlah Besar Orang (The Greatest Happiness for The Greatest Number) dalam Keputusan BPSK No. Reg. 004/REG/BPSK-DKI/I/2016

Masyarakat secara umum memiliki kepentingan yang sama yaitu membutuhkan penyelenggaraan peradilan yang sederhana, cepat dan berbiaya ringan (selanjutnya disebut sebagai efektivitas dari segi hukum secara prosedural). Penanda efektivitas mediasi adalah tercapainya akta perdamaian yang termaktub dalam keputusan Badan Penyelesaian Sengketa Konsumen. Dengan demikian Justice for Peace berupa nilai kemanfaatan bagi sejumlah besar orang (the greatest happiness for the greatest number ${ }^{31}$ didapatkan oleh para pencari keadilan, baik pelaku usaha maupun konsumen dalam mediasi ${ }^{32}$. Andhie Saad selaku konsumen dan Turkish Airlines selaku pelaku usaha mendapatkan manfaat dari adanya mediasi yang dilakukan oleh BPSK DKI Jakarta. Konsumen dan pelaku usaha yang memilih menggunakan jalur mediasi dalam mencapai kesepakatan pada umumnya memilih berdasarkan praktisnya penyelesaian melalui mediasi. Jalur tersebut dipilih karena prosesnya sederhana, cepat dan berbiaya ringan.

Hal ini pula yang melandasi para pencari keadilan yaitu pelaku usaha dan konsumen yang lain untuk mendaftarkan perkaranya di BPSK, khususnya BPSK DKI Jakarta yang terletak di Jl. Perintis Kemerdekaan, Bukit Gading Raya 1 No. 3, Kelapa Gading Jakarta Utara, DKI Jakarta. Hal ini sejalan dengan teori Jeremy Bentham yaitu the greatest happiness for the greateds number. Penyelenggaraan

${ }^{31}$ Bandingkan dengan pemikiran dari Walter Bossert dan Kotaro Suzumura, "The Greatest Unhappiness of the Least Number”, Social Choice \& Welfare. Jun2016, Vol. 47 Issue 1, p187-205. 19p. DOI: 10.1007/s00355016-0951-6, yang menawarkan artikulasi alternatif dari "greatest-happiness-of-the-greatest-number" dengan utilitas terukur. Lebih jauh lagi, dengan semangat prinsip pepatah Rawls, mereka mengusulkan prinsip "the greatestunhappiness-of-the-least-number". Sebagai analogi dengan prinsip "greatest-happiness", prinsip "least-happiness" secara formal setara dengan aturan anti-pluralitas. Hasil utama mereka adalah karakterisasi prinsip "the least-unhappiness".

32 Prinsip the greatest happiness of the greatest number ini bukan hanya digunakan sebatas untuk mengukur kemanfaatan dalam bidang hukum. Di bidan kesehatanpun, prinsip ini dipergunakan, misalnya dalam tulisan dari Yot Teerawattananon dan Steve Russell, “The Greatest Happiness of the Greatest Number? Policy Actors' Perspectives on the Limits of Economic Evaluation As A Tool for Informing Health Care Coverage Decisions in Thailand", BMC Health Services Research, 2008, Vol. 8, Special section p1-9. 9p, 1 Chart, 1 Graph. DOI: 10.1186/1472-6963-8-197, yang mengilustrasikan keterbatasan menggunakan informasi evaluasi ekonomi dalam pengambilan keputusan prioritas perawatan kesehatan, yang dirasakan oleh pelaku kebijakan yang berbeda. Dalam penelitian ini, ditunjukkan bahwa konsep memaksimalkan utilitas kesehatan gagal mengenali nilai-nilai sosial penting lainnya dalam membuat keputusan alokasi sumber daya kesehatan. Hal ini menandakan prinsip kemanfaatan dapat digunakan pula untuk mengambil kebijakan yang berkaitan dengan masyarakat, meskipun kebijakan tersebut bukanlah kebijakan hukum pada umumnya. Bandingkan juga dengan Jeffrey M. Robinson, "An Incongruent Amalgamation: John Stuart Mill's Utilitarianism on Naturalism”, Eleutheria. Fall2015, Vol. 4 Issue 2, preceding p30-52. 25p. Lihat pula Katalin Martinás dan Ádám Kerényi, “On The Teory of Human Decisions in the Age of Beneficial Globalization”, Interdisciplinary Description of Complex Systems. Dec2010, Vol. 8 Issue 2, p70-80. $11 \mathrm{p}$. 
mediasi di BPSK Jakarta Barat juga mendukung adanya efektivitas dari segi hukum secara prosedural, karena dengan biaya yang terjangkau, pelaku usaha dan konsumen pencari keadilan bisa mendapatkan kemudahan untuk menyelesaikan sengketa.

\section{Ragaan 2.}

Justice for Peace (Keadilan untuk Perdamaian) Berupa Nilai Kemanfaatan Bagi Sejumlah Besar Orang (The Greatest Happiness for The Greatest Number) dalam

\section{Mediasi}

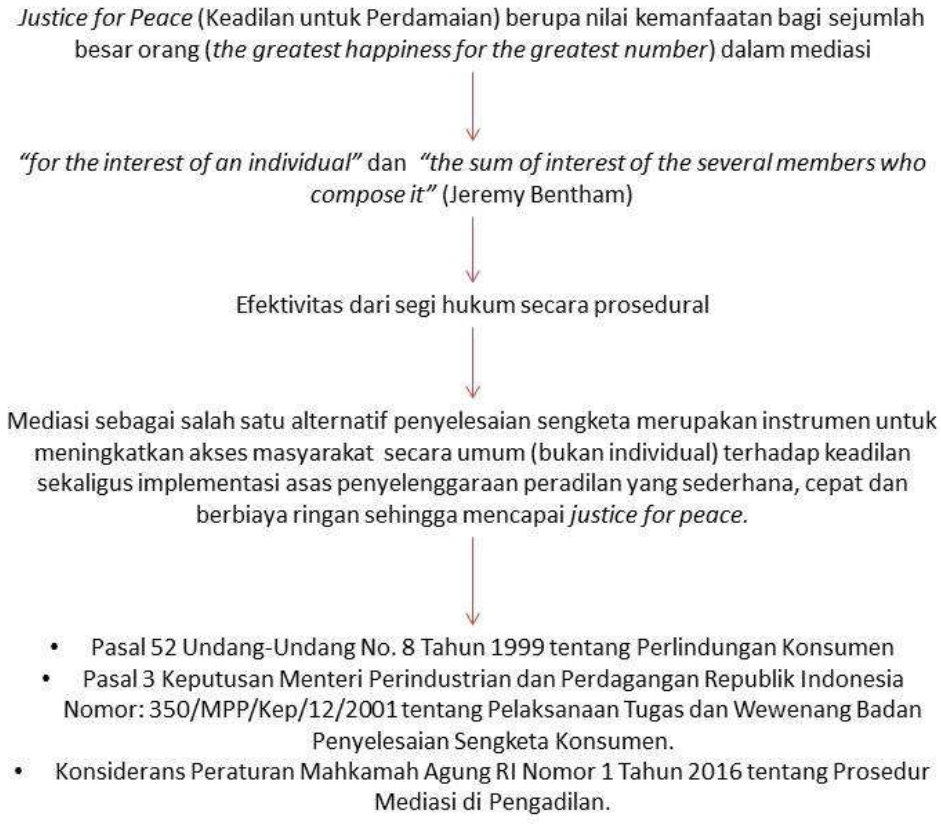

- Konsiderans Peraturan Mahkamah Agung RI Nomor 1 Tahun 2016 tentang Prosedur Mediasi di Pengadilan.

Manfaat secara prosedural yaitu implementasi peradilan yang sederhana, cepat dan berbiaya ringan, sehingga praktek tersebut sejalan dengan peraturannya yang secara normatif terdapat dalam Pasal 52 Undang-Undang No. 8 Tahun 1999 tentang Perlindungan Konsumen, Pasal 3 Keputusan Menteri Perindustrian dan Perdagangan Republik Indonesia Nomor: 350/MPP/Kep/12/2001 tentang Pelaksanaan Tugas dan Wewenang Badan Penyelesaian Sengketa Konsumen, dan Konsiderans Peraturan Mahkamah Agung RI Nomor 1 Tahun 2016 tentang Prosedur Mediasi di Pengadilan. 


\section{Gambar 3.}

\section{Keputusan BPSK No. 001/PM/BPSK-DKI/III/2016}

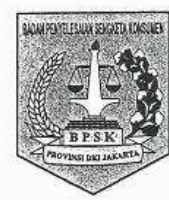

\section{BADAN PENYELESAIAN SENGKETA KONSUMEN \\ ( B P S K ) \\ PROVINSI DKI JAKARTA}

JI. Perintis Kemerdekaan / BGR I No. 2. Jakarta Utara -14240

Telepon: 0851-0186-5368, www.bpsk-dki-jakarta.org bpsk_dki@yahoo.co.id (021) 2245-3426

\section{KEPUTUSAN BPSK \\ No. 001 / PM / BPSK-DKI / III / 2016}

Saya Ketua Badan Penyelesaian Sengketa Konsumen Pemerintah Provinsi DKI Jakarta, menyatakan bahwa :

I. Sesuai dengan :

Formulir Pengaduan Penyelesaian Sengketa dengan Nomor Registrasi 004/REG/BPSK-

DKI/I/2016 tertanggal 22 Januari 2016 atas nama :

1. ANDHIE SAAD ( Konsumen ) yang beralamat di Jl. Cibulan II No. 4 Rt. 003/06 Petogogan, Kebayoran Baru, Jakarta Selatan 12170, Tip. 0816-4855-975, selaku PEMOHON.

2. TURKISH AIRLINES (Pelaku Usaha ) yang beralamat di Prudential Tower Lt. 19, Jl. Jend. Sudirman Kav. 79, Jakarta 10210, Tip. (021) 5795-7666, selaku TERMOHON.

II. Sesuai dengan :

1. Pasal 52 UU No. 8 Tahun 1999 tentang Perlindungan Konsumen Tugas dan Wewenang BPSK meliputi : huruf (a) "melaksanakan penanganan dan penyelesaian sengketa konsumen, dengan cara melalui mediasi atau arbitrase atau konsiliasi".

2. Berita Acara Sidang tanggal 07 Maret 2016, yang isinya antara lain :

1. Konsumen menyatakan, antara lain :

a. Setuju menerima angka sebesar Rp. 20.500.000,-

b. Ditransfer pada rekening Bank BCA KCU Sudirman No. 0350693459 atas nama Andhie Saad paling lambat 14 hari kerja sejak keputusan ini.

2. Wakil Pelaku Usaha dapat memenuhi usul Majelis untuk mempertimbangkan angka sebesar Rp. 20.500.000,--

Pelaksanaan :

- Berdasarkan bukti setoran dari Pelaku Usaha kepada Andhie Saad pada tanggal 16 Maret 2016 sebesar Rp. 2.986.000,- dan pada tanggal 17 Maret 2016 sebesar Rp. 17.514.000,- sebagai pembayaran uang damai, maka kasus No. Reg 004/REG/BPSK-DKI/I/2016 tertanggal 22 Januari 2016 dinyatakan selesai dan ditutup penanganannya di BPSK Prov. DKI Jakarta.

Dengan menimbang hal-hal tersebut diatas, Saya Ketua BPSK Provinsi DKI Jakarta menetapkan bahwa perkara pengaduan tersebut di atas dinyatakan Selesai dan ditutup penangannya di BPSK Provinsi DKT Jakarta.

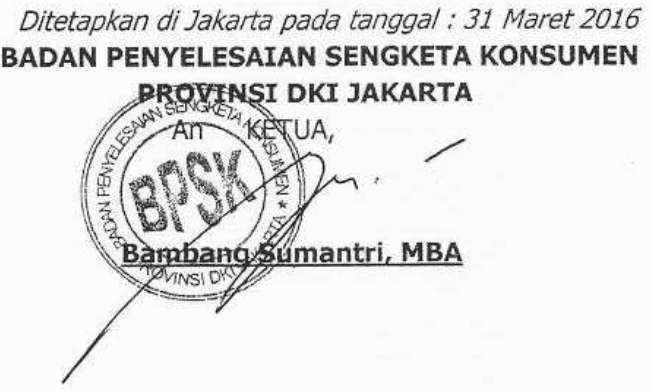

Sumber: BPSK DKI Jakarta 
Menakar Justice for Peace (Keadilan untuk Perdamaian) berupa Kesetaraan (Fairness) Para Pihak dalam Keputusan BPSK No. Reg. 004/REG/BPSKDKI/I/2016

Kesetaraan merupakan kedudukan alamiah yang diinginkan oleh para pihak yang bersengketa. Konsumen maupun pelaku usaha memiliki kesetaraan dalam memperjuangkan haknya dalam proses peradilan termasuk di dalamnya proses mediasi. Bahwa kemanfaatan secara material sejatinya terletak pada bagaimana hukum dapat mengakomodasi masalah dan memberikan jalan keluar secara fair, karena dengan demikian, hukum menjalankan fungsinya sebagai pemberi keadilan bagi setiap pencari keadilan sebagai efektivitas dari segi hukum secara material. Jika bukan melalui hukum, maka melalui jalan apa lagi para pencari keadilan mendapatkan apa yang dicarinya?

Ragaan 2.

Justice for Peace (Keadilan untuk Perdamaian) berupa Kesetaraan (Fairness) Para Pihak dalam Mediasi

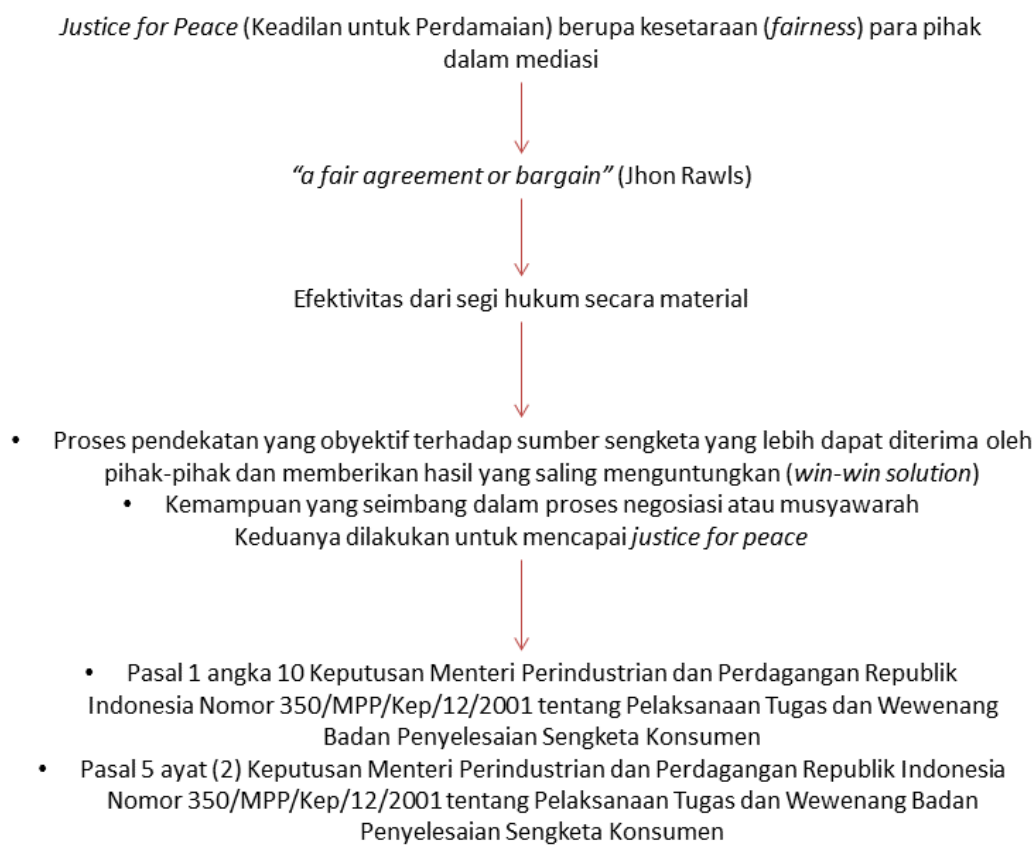

Seperti yang telah dikemukakan pada bahasan sebelumnya definisi mediasi dalam Kepmenperindag No. 350 mengandung kalimat "penyelesaiannya diserahkan kepada para pihak". Kalimat tersebut mengandung prinsip kesetaraan posisi para pihak dalam mengambil keputusan. Badan Penyelesaian Sengketa Konsumen (BPSK) berkedudukan sebagai penasehat bagi kedua belah pihak. Mediasi merupakan pengembangan dari negosiasi, dimana dalam negosiasi para 
pihak sendiri yang melakukan pembicaraan untuk mencapai win-win solution, sedangkan di dalam mediasi, para pihak dibantu oleh BPSK sebagai penengah dalam mencapai win-win solution. Keputusan untuk win-win solution itu ditentukan oleh beberapa faktor ${ }^{33}$ :

“a. Proses pendekatan yang obyektif terhadap sumber sengketa yang lebih dapat diterima oleh pihak-pihak dan memberikan hasil yang saling menguntungkan, dengan catatan bahwa pendekatan itu harus menitikberatkan pada kepentingan yang menjadi sumber sengketa dan bukan pada posisi atau kedudukan para pihak.

b. Kemampuan yang seimbang dalam proses negosiasi atau musyawarah. Perbedaan kemampuan tawar-menawar akan menyebabkan adanya penekanan oleh pihak yang satu terhadap yang lain."

Sifat mediasi yang menghasilkan keputusan win-win solution tersebut tercantum dalam Kepmenperindag No. 350, yaitu ${ }^{34}$ : "Penyelesaian sengketa konsumen dengan cara mediasi dilakukan sendiri oleh para pihak yang bersengketa dengan didampingi oleh Majelis yang bertindak aktif sebagai mediator."

Kesetaraan merupakan hal yang terlihat dalam keputusan BPSK No. 001/PM/BPSK-DKI/III/2016 dimana baik pihak pelaku usaha maupun konsumen pencari keadilan yang melakukan tawar-menawar secara objektif, dapat memperjuangkan haknya masing-masing secara adil. Hal tersebut kemudian tercantum dalam keputusan yang memuat Berita Acara Sidang pada tanggal 07 Maret 2016, berikut ini:

"Konsumen menyatakan, antara lain:

a. Setuju menerima angka sebesar Rp. 20.5000.000,-

b. Ditransfer pada rekening Bank BCA KCU Sudirman No. 0350693459 atas nama Andhie Saad, paling lambat 14 hari kerja sejak keputusan ini.

Wakil Pelaku Usaha dapat memenuhi usul Majelis untuk mempertimbangkan angka sebesar Rp. 20.500.000,-“

Hal ini memperlihatkan kemanfaatan secara material terpenuhi karena mediasi dapat mengakomodasi masalah dan memberikan jalan keluar secara fair dengan cara terang dan tunai. Kesepakatan (mutual consent) di antara Andhie Saad

33 Maria S. W. Sumardjono, dkk, Mediasi Sengketa Tanah: Potensi Penerapan Alternatif Penyelesaian Sengketa (ADR) di Bidang Pertanahan, Gramedia, Jakarta, 2008, hlm. 4

34 Pasal 5 ayat (2) Keputusan Menteri Perindustrian dan Perdagangan Republik Indonesia Nomor 350/MPP/Kep/12/2001 tentang Pelaksanaan Tugas dan Wewenang Badan Penyelesaian Sengketa Konsumen 
dan Turkish Airlines tertera secara jelas, berupa hak dan kewajiban masing-masing pihak. BPSK DKI Jakarta mendorong para pihak untuk saling memenuhi kewajibannya seperti yang tertera dalam mutual consent tersebut.

Pendekatan win-win solution tidak sepenuhnya merupakan penyelesaian sengketa yang memenuhi kepastian hukum secara material, melainkan merupakan pengejawantahan rasa keadilan di antara kedua belah pihak. Andhie Saad sebagai konsumen dan Turkish Airlines sebagai pelaku usaha mungkin tidak bisa memperoleh secara utuh haknya, tetapi rasa keadilan yang tercapai adalah titik temu dari dua kepentingan. Titik temu yang merupakan hasil pertemuan dari kesepakatan yang memberi kemanfaatan wajar bagi kedua belah pihak tersebut.

Dalam proses berperkara, Andhie Saad sebagai konsumen dan Turkish Airlines sebagai pelaku usaha dianggap bebas dan rasional dalam menentukan mutual consent di antara mereka, sehingga adalah hal yang fair, jika masing-masing pihak juga melakukan tanggung jawabnya sesuai dengan keputusan bebas dan rasional tersebut, sehingga sejatinya para pihaklah yang menyelesaikan perkara sendiri. BPSK DKI Jakarta berperan aktif untuk mendukung kesepakatan yang dibuat oleh kedua belah pihak tersebut. Hal ini sesuai dengan jiwa penyelesaian perkara oleh para pihak secara fair oleh John Rawls dan Pasal 1 angka 10 Keputusan Menteri Perindustrian dan Perdagangan Republik Indonesia Nomor 350/MPP/Kep/12/2001 tentang Pelaksanaan Tugas dan Wewenang Badan Penyelesaian Sengketa Konsumen dan Pasal 5 ayat (2) Keputusan Menteri Perindustrian dan Perdagangan Republik Indonesia Nomor 350/MPP/Kep/12/2001 tentang Pelaksanaan Tugas dan Wewenang Badan Penyelesaian Sengketa Konsumen.

Menakar Justice for Peace (Keadilan untuk Perdamaian) berupa Validitas Hukum (Legal Validity) dalam Keputusan BPSK No. Reg. 004/REG/BPSKDKI/I/2016

Kepastian hukum pada awalnya diterjemahkan sebagai validitas hukum (legal validity). Validitas hukum BPSK dinyatakan dalam Keputusan Menteri Perindustrian dan Perdagangan Republik Indonesia Nomor 350/MPP/Kep/12/2001 tentang Pelaksanaan Tugas dan Wewenang Badan 
Penyelesaian Sengketa Konsumen, yaitu ${ }^{35}$ : Keputusan BPSK merupakan putusan yang final dan telah mempunyai kekuatan hukum yang tetap."

Ragaan 3.

Justice for Peace (Keadilan untuk Perdamaian) berupa Validitas Hukum (Legal

Validity) dalam Mediasi

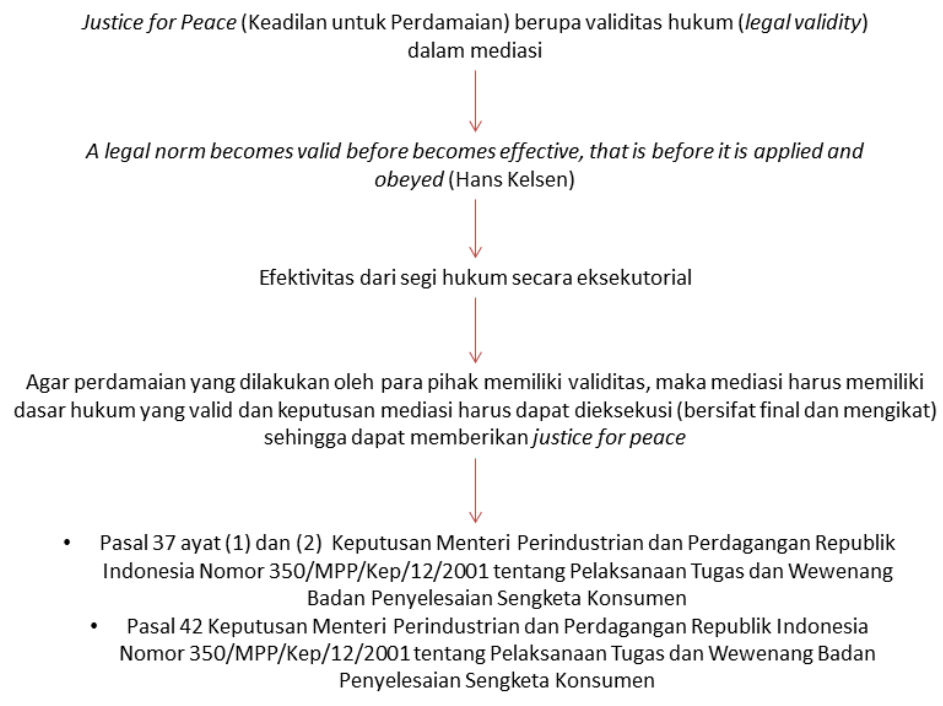

Oleh karenanya, keputusan mediasi harus final dan mengikat. Dengan demikian, secara normatif, keputusan BPSK memiliki validitas hukum (legal validity) yang memberikan kepastian hukum kepada para pencari keadilan baik pelaku usaha maupun konsumen sehingga pada akhirnya mendatangkan Justice for Peace. Validitas hukum juga merupakan salah satu yang diperjuangkan oleh majelis hakim BPSK DKI Jakarta. Dalam perkara Andhie Saad sebagai konsumen dan Turkish Airlines terdapat putusan yang final dan mengikat karena pelaksanaan kesepakatan dilaksanakan di depan hakim ${ }^{36}$. Hal tersebut tertuang dalam keputusan BPSK dalam bentuk pelaksanaan putusan:

“Berdasarkan bukti setoran dari Pelaku Usaha kepada Andhie Saad pada tanggal 16 Maret 2016 sebesar Rp. 2.986.000,- dan pada tanggal 17 Maret 2016 sebesar Rp. 17.514,.000,- sebagai pembayaran uang damai, maka kasus No. Reg. 004/REG/BPSK-DKI/I/2016 tertanggal 22 Januari 2016 dinyatakan selesai dan ditutup penanganannya di BPSK Prov. DKI Jakarta."

35 Pasal 42 Keputusan Menteri Perindustrian dan Perdagangan Republik Indonesia Nomor 350/MPP/Kep/12/2001 tentang Pelaksanaan Tugas dan Wewenang Badan Penyelesaian Sengketa Konsumen

${ }^{36}$ Wawancara dengan Dr. Djainal A. Simanjuntak, Hakim Mediator BPSK DKI Jakarta, 17 Oktober 2016, BPSK DKI Jakarta 
Kasus tersebut selesai penanganannya di BPSK DKI Jakarta. Validitas hukum terterapkan dan keputusan tersebut juga memiliki kekuatan eksekutorial bahkan eksekusi dilakukan di hadapan hakim secara terang dan tunai dengan menunjukkan bukti setoran sebagai pemenuhan kewajibannya. Hal ini sejalan dengan pendapat Hans Kelsen mengenai "a legal norm becomes valid before becomes effective, that is before it is applied and obeyed". Hal ini juga sejalan dengan peraturan yang melandasinya yaitu Pasal 6 ayat (1) dan (2) Keputusan Menteri Perindustrian dan Perdagangan Republik Indonesia Nomor 350/MPP/Kep/12/2001 tentang Pelaksanaan Tugas dan Wewenang Badan Penyelesaian Sengketa Konsumen dan Pasal 42 Keputusan Menteri Perindustrian dan Perdagangan Republik Indonesia Nomor 350/MPP/Kep/12/2001 tentang Pelaksanaan Tugas dan Wewenang Badan Penyelesaian Sengketa Konsumen.

Keputusan BPSK No. 001/PM/BPSK-DKI/III/2016 merupakan keputusan yang mencerminkan penyelesaian sengketa konsumen yang mengandung nilai kemanfaatan, keadilan dan kepastian hukum sehingga pada akhirnya mendatangkan Justice for Peace bagi konsumen dan pelaku usaha pencari keadilan.

\section{Penutup}

Penyelesaian Sengketa Konsumen melalui Badan Penyelesaian Sengketa Konsumen (BPSK) dalam keputusan BPSK No. Reg. 004/REG/BPSK-DKI/I/2016 memenuhi nilai-nilai Justice for Peace. Pemenuhan nilai-nilai Justice for Peace searah dengan konsep kemanfaatan, keadilan dan kepastian hukum yang diilhami oleh konsep "the sum of interest of the several members who compose it" (Jeremy Bentham) "a fair agreement or bargain" (Jhon Rawls), dan "a legal norm becomes valid before becomes effective, that is before it is applied and obeyed" (Hans Kelsen). Kemanfaatan, keadilan dan kepastian hukum tersebut sejalan pula dengan semangat mediasi yang terdapat dalam peraturan perundang-undangan tentang efektivitas hukum dari segi prosedural, material dan eksekutorial terutama yang tercantum dalam Undang-Undang No. 8 Tahun 1999 tentang Perlindungan Konsumen, Keputusan Menteri Perindustrian dan Perdagangan Republik Indonesia Nomor 350/MPP/Kep/12/2001. 
Adapun hasil penelitian yang telah diuraikan di atas penulis dapat memberikan sarana. Pertama, penyelesaian sengketa melalui jalur mediasi melalui BPSK hendaknya merupakan salah satu pilihan yang layak untuk dipertimbangkan oleh konsumen dan pelaku usaha sebagai pencari keadilan. Kedua, kiranya mediasi dipandang dari sudut pandang justice as fairness untuk mencapai kedamaian (peace), bukan hanya dari sudut kemanfaatan saja berupa dapat dilakukannya tawar-menawar untuk mencapai titik temu. Bahwa hak obyektif dari para pihak pencari keadilan juga layak untuk diperjuangkan dalam mediasi.

\section{Daftar Pustaka}

\section{Buku}

Bentham, Jeremy, An Introduction to the Principles of Moral and Legislation Kitchener, Ontario, 2000.

Fuady, Munir, Teori-teori Besar (Grand Theory) dalam Hukum, Prenada Media Group, Jakarta, 2013.

Harahap, Yahya M., Hukum Acara Perdata: Tentang Gugatan, Persidangan, Penyitaan, Pembuktian dan Keputusan Pengadilan, Sinar Grafika, Jakarta, 2007.

Kelsen, Hans, Introduction to The Problem of Legal Theory, Oxford University Press, New York, 2002.

Margono, Suyud, ADR (Alternative Dispute Resolution) dan Arbitrase Proses Pelembagaan dan Aspek Hukum, Ghalia Indonesia, Bogor, 2004.

Marzuki, Mahmud Peter, Penelitian Hukum, Kencana, Jakarta, 2006.

Nasution, Az, Hukum Perlindungan Konsumen Suatu Pengantar, Penerbit Diadi, Jakarta, 2006.

Nugroho, A. Susanti, Mediasi Sebagai Alternatif Penyelesaian Sengketa Cetakan ke-2, Telaga Ilmu Indonesia, Tangerang, 2011.

Penyelesaian Sengketa Arbitrase dan Penerapan Hukumnya, Prenada, Jakarta, 2015.

- Proses Penyelesaian Sengketa Konsumen Ditinjau dari Hukum Acara serta Kendala dan Implementasinya, Prenada, Jakarta, 2011.

Rawls, John, A Theory of Justice, Harvard University Press, Cambridge, 1991.

Satjipto Raharjo, Hukum dan Perubahan Sosial, PT. Citra Aditya Bakti, Bandung, 1980.

, Ilmu Hukum, PT. Citra Aditya Bakti, Bandung, 2006. 
Sembiring, Jimmy Joses, Cara Menyelesaikan Sengketa di Luar Pengadilan; Negosiasi, Mediasi, Konsiliasi, E Arbitrase, Visimedia, Jakarta, 2011.

Sumardjono, Maria S. W., et al., Mediasi Sengketa Tanah: Potensi Penerapan Alternatif Penyelesaian Sengketa (ADR) di Bidang Pertanahan, Gramedia, Jakarta, 2008.

Soejono Soekanto, Faktor-Faktor yang Mempengaruhi Penegakan Hukum, Raja Grafindo Persada, Jakarta, 1983.

Umam, Khotibul, Penyelesaian Sengketa di Luar Pengadilan, Pustaka Yustisia, Yogyakarta, 2010.

Usman, Rachmadi, Pilihan Penyelesaian Sengketa di Luar Pengadilan, PT. Citra Aditya Bakti, Bandung, 2003.

\section{Kamus}

Cambridge Advanced Learner's Dictionary, $4^{\text {th }}$ Edition, edited by Colin Mc. Intosh, Cambridge University Press, United Kingdom, 2013.

\section{Peraturan Perundang-Undangan}

Undang-Undang No. 8 Tahun 1999 tentang Perlindungan Konsumen

Keputusan Menteri Perindustrian dan Perdagangan Republik Indonesia Indonesia, Nomor: 350/MPP/Kep/12/2001

Peraturan Mahkamah Agung RI Nomor 1 Tahun 2016 tentang Prosedur Mediasi di Pengadilan.

\section{Jurnal}

Armstrong, Kimberley, "Justice without Peace? International Justice and Conflict Resolution in Northern Uganda", Development E Change, May2014, Vol. 45 Issue 3, p589-607, 19p. DOI: 10.1111/dech.12090.

Bossert, Walter, dan Suzumura, Kotaro, "The Greatest Unhappiness of the Least Number Social Choice \& Welfare", Jun2016, Vol. 47 Issue 1, p187-205, 19p. DOI: $10.1007 /$ s00355-016-0951-6.

Cordelli, Chiara, "Justice as Fairness and Relational Resources", Journal of Political Philosophy, Mar2015, Vol. 23 Issue 1, p86-110, 25p. DOI: 10.1111/jopp.12036.

Gérard, Philippe, “On Some Presuppositions of Judgments of Legal Validity”, Ratio Juris, Jun2016, Vol. 29 Issue 2, p280-287, 8p. DOI: 10.1111/raju.12128.

Hadiati, Mia dan Mariske Myeke Tampi, “Efektivitas Mediasi dalam Penyelesaian Sengketa Konsumen oleh Badan Penyelesaian Sengketa Konsumen (BPSK) di D.K.I. Jakarta", Jurnal Hukum Prioris, Volume 6 No. 1 Tahun 2017, 64-80.

Klijnsma, Josse, "Contract Law as Fairness", Ratio Juris, Mar2015, Vol. 28 Issue 1, p68-88. 21p.

Kramer, Matthew H, "Moral Principles and Legal Validity", Ratio Juris, Mar2009, Vol. 22 Issue 1, p44-61, 18p. DOI: 10.1111/j.1467-9337.2008.00411.x.

Lawrence, Michael Anthony, "Justice-as-Fairness as Judicial Guiding Principle", Brooklyn Law Review, Winter2016, Vol. 81 Issue 2, p673-731, 59p. 
Martinás, Katalin, dan Kerényi, Ádám, “On The Teory of Human Decisions in the Age of Beneficial Globalization", Interdisciplinary Description of Complex Systems, Dec2010, Vol. 8 Issue 2, p70-80, 11p.

Pino, Giorgio, "Positivism, Legal Validity, and Separation of Law and Morals", Ratio Juris, Jun2014, Vol. 27 Issue 2, p190-217, 28p. DOI: 10.1111/raju.12044.

Robinson, Jeffrey M, “An Incongruent Amalgamation: John Stuart Mill's Utilitarianism on Naturalism", Eleutheria, Fall2015, Vol. 4 Issue 2, preceding p30-52. 25p.

Teerawattananon, Yot, dan Russell, Steve, "The Greatest Happiness of the Greatest Number? Policy Actors' Perspectives on the Limits of Economic Evaluation As A Tool for Informing Health Care Coverage Decisions in Thailand", BMC Health Services Research, 2008, Vol. 8, Special section p1-9. 9p. 1 Chart, 1 Graph. DOI: 10.1186/1472-6963-8-197.

Weinberger, Ota, “Legal Validity, Acceptance of Law, Legitimacy: Some Critical Comments and Constructive Proposals", Ratio Juris, Dec1999, Vol. 12 Issue 4, p336, 18p.

\section{Keputusan}

Keputusan BPSK No. Reg. 004/REG/BPSK-DKI/I/ 2016 tertanggal 22 Januari 2016 Wawancara

Wawancara dengan Dr. Djainal A. Simanjuntak, Hakim Mediator BPSK DKI Jakarta, 17 Oktober 2016, BPSK DKI Jakarta, Jl. Perintis Kemerdekaan/BGR I No. 2, Jakarta Utara - 14240

Wawancara dengan Bpk. Jerry Ephraim Caraen, Kepala Seksi Konsultasi Hukum Sub Direktorat Pemberdayaan dan Perlindungan Konsumen, 19 Oktober 2016, Kementerian Perdagangan Republik Indonesia, Jl. M Ridwan Rais No. 5, Jakarta Pusat - 10110 